\title{
Progressive Management Tools for Quality Improvement
}

\author{
Application to transport market and railway transport
}

\author{
Eva Nedeliakova, Michal Panak, Jan Ponický \\ University of Zilina \\ FPEDAS, Department of Railway Transport \\ Zilina, Slovakia \\ eva.nedeliakova@fpedas.uniza.sk
}

\author{
Radovan Sousek \\ University of Pardubice \\ Jan Perner Transport Faculty, Transport Technology Unit \\ Pardubice, Czech Republic \\ radovan.sousek@upce.cz
}

\begin{abstract}
Situation in the transport market worldwide is currently characterized by high competition, fluctuating demand and shorter product life cycle. These factors are putting pressure on the managers of railway undertakings towards cost reduction, flexibility in services offer, efficiency of management and technologies of transport and shipping processes, transportation logistics and risk management. The paper deals with important results of research that emphasize progressive management tools as a way to the ability of a railway undertaking to react on change, improve its processes quality and immediately identify risks, define critical points and consequently adopt strategies for its elimination.
\end{abstract}

Keywords-Progressive management tool; quality improvement; transport market; railway transport

\section{INTRODUCTION}

Constantly changing market environment is largely affected by the need to respond flexibly with appropriate change management, which is extremely difficult and in terms of rail transport very specific task [2]. A railway undertaking is affected by risks of internal environment, external, similarly interactive [3].

In the transport market the railway transport is an important branch of transport [7]. Its crucial advantages are the lowest negative impact on the environment, the highest level of security among the land transport modes, the lowest specific energy consumption, high degree of safety and others [5]. These factors must be monitored by the management of railway transport so it goes hand in hand with the world traffic trends [1].

Characteristic is connecting of speed, safety, and economy, while highlighting quality as an integral part of the services offered in passenger and freight transport [7]. There are many causes of risk formation and their consequences that significantly affect the operation of any enterprise and relate to personnel, technical or technological problems. The risks may relate to strategic decisions, crisis, but also the structure of assets and funding opportunities of the company [6].

Railway undertaking is any public or private company licensed according to applicable legislation, which the principal business is to provide services to ensure the rail transport of goods or persons, while the undertaking must ensure traction, including companies which provide only the traction [5].

The process is understood as a summary of mutually arranged activities changing inputs into outputs by consumption of certain resources in controlled conditions. Inputs delivered by internal or external suppliers are entirely consumed for the process outputs. Some resources are not consumed in the process, but are a requisite for its implementation (e.g. people, machinery, technology, information systems, etc.). Tangible outputs (products) and intangible outputs (services) are the result of processes that have particular customer [10].

The transport process is represented by successive actions in terms of time by which is performed and provided the traffic [12].

\section{IMPROVEMENT OF THE QUALITY}

\section{A. Transport market participants interests}

Improvement of the quality of services provided, the removal of existing deficiencies and regular monitoring of needs make it possible to convince the customer that the primary objective of the company is its satisfaction.

In general, transport market participants have certain targets, the fulfilment of which they follow.

The interest of an infrastructure manager focuses primarily on:

- the most efficient use of railway infrastructure,

- cost reduction for maintenance and upgrading of railway network in compliance with all continuity and safety conditions,

- modernization of selected tracks included in the international corridors [8].

The interest of the railway undertaking focuses on:

- success in the transportation market, 
- operation of processes without faults and incidents,

- minimum reduction of damages related to harm to life, health or property,

- reduction of transport operation costs,

- increase in revenues from transport, ancillary services and total profits,

- building of a good reputation, expertise recognition and financial stability [9].

\section{B. Criteria for success of railway transport}

The customer will be convinced that he opted for the best partner to transport them or their goods. The example of success criteria, in application on freight transport is described in the Fig. 1 [11].

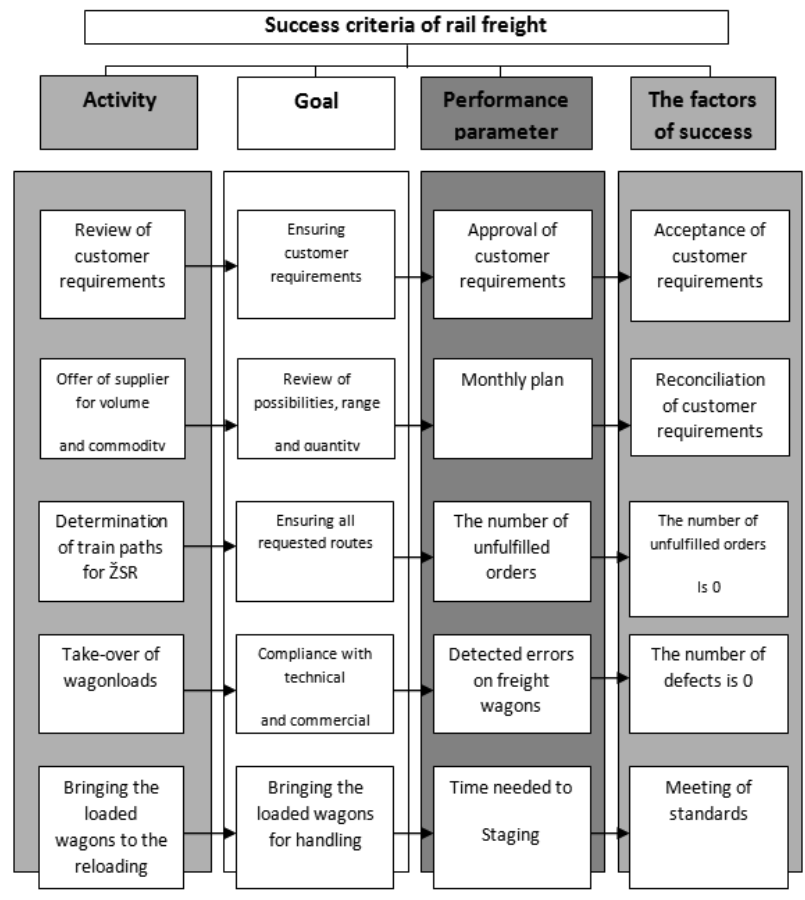

Fig. 1. Criteria for success of rail freight

The way to success leads mostly through the quality services and rational operation of traffic and transport processes.

The customer's interest focuses in particular on:

- affordable price,

- availability of services,

- ease of transfer selection,

- the minimum time between the establishment of transport requirement and its implementation,

- the shortest time of transport or delivery period,
- ease of administration associated with the transport of goods,

- reduction of changes or transhipments number,

- fast delivery at a specified time for some commodities,

- reduction of waiting times for the relevant connections or takeover of the consignment to transport,

- regular and numerous connections,

- comfort during transportation, protection of shipments,

- accurate information about the services offered and the current state of transportation.

- security of transport [13].

According to these statements, research has shown that improvement of the quality is really closely connected with change management. Therefore, change management approach is great challenge and it can be considered as a progressive management tool for quality improvement [14].

\section{CHANGE MANAGEMENT AS A TOOL FOR QUALITY IMPROVEMENT}

Change management belongs to very useful elements of successful management. It is important to say that the field of change management is significantly broader as stated in this textbook. However, it represents complex overview on the process of the change. Complexity is rather understood from the complexity approach, regarding individual steps than detailed examination of the individual steps [4].

Change can be defined as excitement, irregularity, news, surprise, negation, and step into unknown. It is connected to risk, unwillingness, sometimes even with resistance. Change represents element that is present in nowadays society, but it is also an element that is very often used in the world economy. It is caused because of the fact that globalization and internationalization cause that current turbulent environment leads to keep competitiveness in the change of small, individual, and also complex, big extent.

Change management principles analyse changes, examine the term change, point how many different forms change can have. Further, they explain levels and phases of the change [6].

There exist several points for classification of the phases. It is convenient to start with division of the change as a project. The project has several phases, and so the change has. Phases have to follow successively and to the successive phase it is not possible to move without detailed analysis of the results from the previous phase.

Businesses can use different models of the change implementation; one of the most complex is change model by Donnelly. Some models move their attention to elements that cause change, and at the same time, they focus on the fact if is suitable to plan change project, or perform unplanned change. Consequences follow in connection to failure of the change.

Innovations and changes can be implemented in various areas. One of the highly relevant areas within organization is 
its organizational structure. Organizational structure is a result of managerial function of organizing. Among basic changes, regarding organization structure that can occur in a railway company, belong renaming of the departments to units, associated with new scope of work, creating new units, cancellation of unprofitable units, renaming of the sections resp. rearrangement [10].

There is a standard structure at the top management level in a railway company, i. e. supervisory board, and board of directors, the secretariat of the board, the internal control and inspection department, as well as the legal department and controlling. Changes always affect mainly individual departments, or teams [11].

In order to fulfil the top business objectives, the strategy has to be defined accurately and as well as relations between employees that are influenced by it. A railway company does not exist only in unchangeable environment, but changeability of external and internal situation of the company requires ability to flexibly change any factor. In many cases there have to be, at an early stage, implementation of the change to the creation of a new organizational structure.

According to [14] "change management is understood as directed effort to identify the need for change, identification of the object changes, planning, implementation, as well as change control”. It is very important that the whole process of change is performed without mistakes, because a small mistake can cause a chain reaction that can lead not only to disintegration and failure of the process of a change, but the company may be at risk, up to the point that enters a recession.

Structural changes must therefore be carried out to identify all possible threats of the change process and defined possible actions against these threats. Organizing and corresponding organizational structures are the main pillars of modern management [12]. They use benefits of division of labour, ensuring the coordination of the necessary actions and relationships between people who implement it. Order, discipline and way of realizing activities make it easier by defining the powers and responsibilities of the people involved in the organized processes.

\section{TYPE OF CHANGE RESEARCH}

Change in railway companies can be performed on the different levels, where the most important change was transformation of railway companies [1]. Change management principles are subsequently applied to changes in organizational structures, but as well as in everyday operation on the transport market. The causes of changes in terms of a railway company can be divided into external and internal [13].

Research results showed that changes in railway companies could have different form:

- change in technology - philosophy, values, way of work, work performance requirements, amount of the employees are changing,

- customers' preferences and transport market changes customers are becoming more demanding, that changes requirements in adopting the market to their preferences,

- changes in organizational structure - new organizational structures emerge and require new employees orientation,

- changes in competition and business environment require quality situation analysis and reaction to new inputs that arose in it,

- changes in procedures and proceedings - require perfect communication and awareness of all hierarchical steps in the organization,

- changes in individuals - employees have to change their habits, attitudes, skills and competences in connection to quickly changing environment.

Management of the changes in a railway company is understood as a project, where following procedures have to be followed:

- defining objective and partial objectives,

- appoint persons, their roles and responsibilities, so called agent of changes,

- the forms and extent of communication,

- create timetable.

Individual phases of the project can be divided to four phases as it is shown in the Fig. 2.

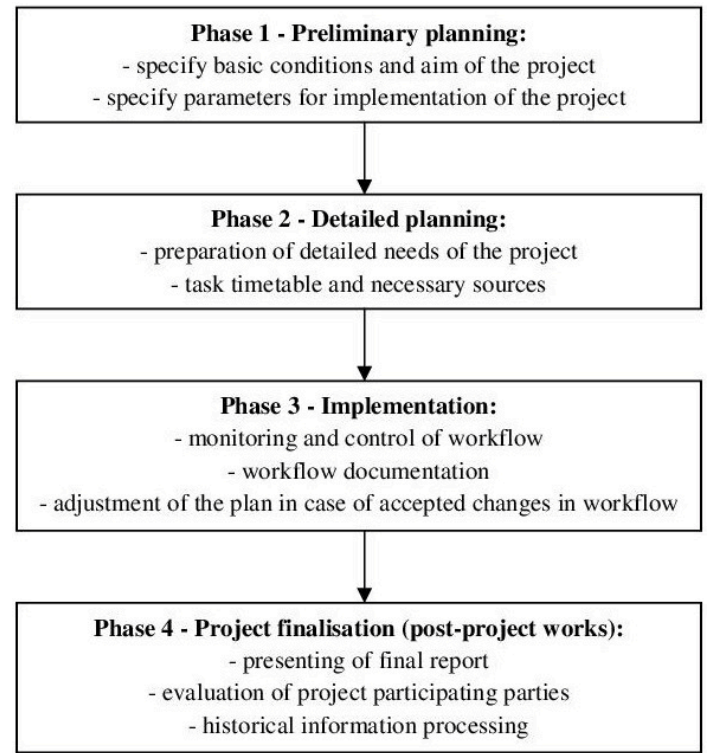

Fig. 2. Individual phases of the project

Successful change requires adjustment of the methods, techniques, strategies and implementing tactics of particular history, culture and people in the company. Process of the changes is rather complicated, however there exist models how to implement the change. 
In practice it is, of course, possible that the change fails. Reasons for failing of the change are different:

- implementation of change took longer than planned,

- implemented activities were not adequately coordinated,

- managers do not display the ability to implement changes,

- instructing of the staff did not bring the desired change in attitudes,

- unforeseeable external factors had a negative impact on the implementation of the change.

\section{CONCLUSION}

There are railway companies that have to continuously deal with increasing completive pressure, which drives out not only from the growing number of market players, the higher demands of customers, but also the globalization tendencies which apply in the current economy. For railway companies it is particularly important to react flexibly to the changing state of the transport market. It leads to various changes that may have a nature of the change of one employee work performance, but a change in the operation of the whole company may occur [11].

According to conducted research, it is necessary to get economic parameters of railway companies at a comparable level with developed foreign railway administrations. On one hand, there is constant pressure to reduce costs; on the other hand, there is a need to look for opportunities to increase revenues.

However, railway companies are operating in the area affected by the economy, as well as the existing state transport policy. Encouraging the development of environmentally friendly means of transport in the framework of the principles already valid in the countries worldwide should be included into the transport policy.

Research has shown that well prepared change management is one of the most important approaches to quality improvement.

The project of the change has successive different phases. The first phase of planning includes modelling of various solutions and the development of the schedule. The second phase involves individual solving teams, fulfilment of the objectives, defining key performance indicators and processing of the final design of the change. The third phase includes feedbacks and corrections of original decisions.

One objective of the change is to increase the transparency of operating procedures, powers and responsibilities of each employee. These changes have the effect of transforming the company into a modern, process-controlled and dynamic organization that can flexibly respond to market needs and customers' expectations in both passenger and freight transportation.
Each project has set targets that must be measurable and achievable. Key performance indicators must be defined for measurability of goals. To make reaching goals realistic, it is possible to use allocating method of whole big project to a number of smaller subprojects.

\section{ACKNOWLEDGMENT}

This paper is prepared with the support of the project KEGA [No 026ŽU-4/2015] Innovative approaches in the system of teaching management in the railway transport study program with a focus on the application of dynamic quality models in railway transport.

\section{REFERENCES}

[1] A. Brown, "Industrial Experience with Total Quality Management". Total Quality Management, vol. 3, iss. 2, 1992, pp. 147-156.

[2] D. Hrašková, V. Bartošová, “Critical factors of Managing Change in the transport company,” in Economics - Management Spectrum: scientific journal of Faculty of Operation and Economics of Transport and Communications, 7th ed. vol. 2, University of Žilina in Žilina, 2013, pp.51-55.

[3] E. Nedeliaková, A. Dolinayová, I. Nedeliak, "Methods of evaluation of the transportation services quality”, University of Žilina in Žilina, EDIS, 2013.

[4] E. Nedeliaková, I. Nedeliak, P. Majerčák, P., "Research of services quality after the end of transportation in railway freight transport”. Singapore: Singapore Management and Sports Science Institute, 2014, p. 54-61.

[5] I. Kubasáková, M. Šulgan, "Modern logistic system - effective customer response (ECR)" in Transport and communications, University of Žilina in Žilina, 2005, pp. 5-10.

[6] J. Antony, R. Banuelas, R., "Key Ingredients for the Effective Implementation of Six Sigma Program. Measuring Business Excellence”, 6(4), 2002, pp. 20-27.

[7] J. Majerčák, I. Nedeliak, "Practical experiences with modeling of IT systems and business processes," in 6th Forum of rail transport, Bratislava, 2010, pp. 81-84.

[8] J. Sekulová, I. Nedeliak, "Utilization of GAP model in providing of services in the railway freight transport," in Perner's Contacts, 8th ed. vol. 4, 2013, pp. 67-75.

[9] J. P. Skrinjar, B. Abramovic, N. Brnjac, "The use of game theory in urban transport planning”. Tehnicki Vjesnik-Technical Gazette. Vol. 22, iss. 6, 2015, pp. 1617-1621.

[10] J. Sujanova, P. Gabris, M. Licko, P. Pavlenda, R. Stasiak-Betlejewska, "Aspects of Knowledge Management in Slovak Industrial Enterprises”, in: 13th European Conference on Knowledge Management (ECKM), vols 1 and 2, Univ Politecnica Cartagena, Spain, p. 1135 - 1144.

[11] KEGA 026ŽU-4/2015 "Innovative approaches in system of teaching management in the study program Railway transport with a focus on application the dynamic quality models in the railway transport”, University of Žilina in Žilina, 2015.

[12] M. Poliak, "Current problems of procurement of transport services by public passenger transport," in Current problems in transport 2009, Pardubice: Institut Jana Pernera v Praze with Přepravní laboratoří Dopravní fakulty Jana Pernera, 2009, pp. 213-218.

[13] M. Vetráková, M. Potkány, M. Hitka, “Outsourcing of facility management”, in: E\&M Economics and Management, Vol. 16, No. 1/2013, Liberec: TU Liberec, 2013, p. 80-92.

[14] P. F. Drucker, "Management Challenges for the 21st Century”. New York: HarperCollins Publishers, Inc. 1999. 